\title{
Lipid profile and cardiovascular risk indices of women on various types of contraceptives in the Ho Municipality of Ghana
}

\author{
Ahmed Tijani Bawah ${ }^{1 *}$, Michael Asamoah Boateng ${ }^{1}$, Francis A. Osei Kuffour ${ }^{1}$, \\ Mohammed Mustapha Seini ${ }^{2}$, Paul Amoah ${ }^{3}$, Huseini Alidu ${ }^{1}$
}

\author{
${ }^{1}$ Department of Medical Laboratory Science, School of Allied Health Sciences, University of Health and Allied \\ Sciences, Ho, Ghana \\ ${ }^{2}$ Department of Laboratory, Greater Accra Regional Hospital, Accra, Ghana \\ ${ }^{3}$ Department of Laboratory, Volta Regional Hospital, Ho, Ghana
}

Received: 22 August 2018

Accepted: 27 September 2018

\section{*Correspondence:}

Dr. Ahmed Tijani Bawah,

E-mail: ahmed024gh@yahoo.com

Copyright: (c) the author(s), publisher and licensee Medip Academy. This is an open-access article distributed under the terms of the Creative Commons Attribution Non-Commercial License, which permits unrestricted non-commercial use, distribution, and reproduction in any medium, provided the original work is properly cited.

\section{ABSTRACT}

Background: Hormonal contraceptives (HCs) have been successfully used worldwide to prevent pregnancy by inhibiting ovulation and implantation. These contraceptives have effects on lipid metabolism, body fat and blood pressure which are all risk factors for cardio vascular disease (CVD). Some studies have reported that prolonged use of these hormone-based contraceptives have negative effect on cardiovascular risk indices, however, few of such studies have been done in Ghana, hence this study sought to examine the effect of various forms of contraceptives on cardio vascular risk indices in the Volta Region of Ghana.

Methods: Purposive random sampling was employed in selecting women on various forms of contraceptives and aged-matched controls into the study. Fasting blood sample was collected from each participant after overnight fast for 10-16 hours into plain tubes and the sera used to determine lipid profile. Socio-demographic and BMI variables were also analyzed in this case-control study.

Results: Statistically significant differences were observed for Diastolic Blood Pressure (DBP) (p=0.0153), High Density Lipoprotein levels (HDL) $(p=0.001)$, and the atherogenic index $(p=0.0101)$ between the cases and the controls.

Conclusions: The use of HC significantly affects the DBP, HDL and atherogenic index and these could pose substantial risk for the development of CVD.

Keywords: Blood pressure, Cardiovascular disease, Hormonal contraceptive, Implant, Lipid profile, Oral contraceptive

\section{INTRODUCTION}

There is the need to balance sexual excitement and fertility control taking into consideration some of the reported effects of $\mathrm{HCs}$ on their users and the fact that other alternative methods of contraceptive are available. Dyslipidemia and weight gain as consequences of $\mathrm{HCs}$ have been reported by some researchers but very few of such studies have been done in the Volta Region of Ghana. It is against this background that this study sought to examine lipid profile and cardiovascular risk indices among women using various forms of contraceptives in the Ho municipality of the Volta Region. Birth control has been used for so many years to control the number of children in families, however, wide spread use of contraceptives started in the 1960s. 
This was followed by researchers in the United States of America putting in measures to balance its effects and relevance on its users. ${ }^{1}$ Some women complain of weight gain resulting from hormonal contraceptive use and studies done earlier in the Upper West Region of Ghana associated dyslipidemia with prolonged use of these birth control measures. ${ }^{2}$ The need to practice family planning cannot be overemphasized and so there is the need to focus on the short to medium term use of contraceptives and cardio vascular risk factors.

Several methods are available for fertility control; however, the most effective ones are vasectomy in males, tubal ligation, intrauterine devices (IUDs) and the use of implants in females. ${ }^{3}$ Other methods of contraceptives are; the oral contraceptives (OC) pills, vaginal rings, injections and patches all of which are hormone-based. ${ }^{3}$ The rest are; condoms, diaphragms, birth control sponges, spermicides and withdrawal before ejaculation by the male. ${ }^{3}$ Generally, fertility control methods can be divided into hormone-based and non-hormone-based contraceptives. The most popular hormonal contraceptives in Ghana are: the OC pills, Implanon NXT, Depo-Medroxyprogesterone acetate, Norigynon, Microgynon, and Microlut, however, the most preferred ones among women attending the family planning clinics in Ghana are: Depo-Provera (depot medroxyprogesterone acetate) (DMPA), an injectable contraceptives (IC) and oral contraceptives $(\mathrm{OC}){ }^{2}$

Aside the primary roles of controlling birth, most of these hormonal contraceptives have effects on carbohydrate and lipid catabolism. ${ }^{4}$ Some research has reported a $22 \%$ rise in Low Density Lipoprotein (LDL) cholesterol among users of combined oral contraceptive (COC) without a concomitant increase in HDL resulting in a reduction of HDL/LDL ratio. ${ }^{5}$ Furthermore prolonged use of oral contraceptives decreases glucose tolerance over time by increasing insulin resistance and decreasing beta cell function. ${ }^{6,7}$ In another study, the injectable contraceptive; depot medroxyprogesterone acetate was reported to cause increases in LDL cholesterol levels and decreases in HDL cholesterol concentration. ${ }^{8}$

A lot of modifications have been made on the $\mathrm{HCs}$ in order to reduce the undesirable effects of these fertility control methods, however, HCs still pose considerable thromboembolic risk, a rise in blood pressure and a recent study has reported a link between contraceptive use and albuminuria, a marker for endothelial damage. ${ }^{9-11}$

\section{METHODS}

This cross sectional-case-control study was carried out from December 2017 to March 2018 and involved participants between 16 to 49 years old who were on various forms of contraceptives such as oral contraceptive, subdermal implant, injectable contraceptive and copper intra uterine devices (IUDs) with no previous history of cardio vascular diseases or risk factors. The study protocol was reviewed and approved by the University of Health and Allied Sciences' Research Ethical Committee (Protocol number: UHAS-REC/A.5 [40] 17-18). Informed consent was obtained from each of the clients prior to sample taking. Ninety participants took part in the study made up of 65 cases on various forms of contraceptives and 25 agematched controls. Participants' information such as age, duration and the types of contraceptives used by clients, were obtained from the registration book at the family planning units of Volta Regional Hospital (VRH) and Ho Municipal Assembly Health Centre. Anthropometric markers such as height and the weight of clients were measured, and the Body Mass Index was computed as weight/height $\left(\mathrm{kg} / \mathrm{m}^{2}\right)$. The blood pressure was measured and recorded as systolic blood pressure (SBP) and diastolic pressure (DBP) $(\mathrm{mmHg})$. Five millilitres of venous blood was obtained by venepuncture after overnight fast of 10 to 16 hours and put into plain tubes and allowed to clot and then centrifuged within 1 hour at 3000rmp for 10 minutes. Serum samples were obtained and stored in small aliquots at $-21^{\circ} \mathrm{C}$ until analysis. All samples were analysed within 1 week after collection.

The Lipid Profile was determined using the Selectra Pro S (Vital Scientific B.V. Van Rensselaerwweg 4, NL 6956 AV Spankeren, The Netherlands) automated chemistry analyzer using the procedure outlined for the equipment.

\section{Statistical analysis}

Data was entered in Microsoft Excel (2016) software program and doubly checked for errors before being exported to SPSS (v20.0; IBM Corporation, Armonk, NY, USA) for analysis. Data for the different Lipid parameters were expressed as mean $( \pm \mathrm{SD})$. Lipid parameters between case and control groups were compared using $t$-test. A P-value of $<0.05$ was considered statistically significant.

\section{RESULTS}

A total of 90 participants took part in the study with the minimum and the maximum age of participants being 16 and 49 years respectively.

Table 1: Bio-demographics of the study respondents.

\begin{tabular}{|lll|}
\hline Parameters & Frequency & Percentage \\
\hline Total respondents & 90 & 100 \\
\hline Status & & \\
\hline Case & 65 & 72.22 \\
\hline Control & 25 & 27.78 \\
\hline Age (years) & & \\
\hline$<20$ & 5 & 5.56 \\
\hline $20-29$ & 40 & 44.44 \\
\hline $30-39$ & 31 & 34.44 \\
\hline $40-49$ & 14 & 15.56 \\
\hline
\end{tabular}


There was no statistical significant difference $(p>0.05)$ in the mean age of the cases $(30.48 \pm 8.07$ years) and the controls (28.92 \pm 9.76 years). Sixty-five of the respondents used various forms of contraceptives; 25 were on subdermal contraceptive implant (Implanon) (Merck and Co, Inc., Whitehouse Station, NJ, USA), a progesterone only contraceptive, 25 were on ICs (Depo-Provera) which is made up of $150 \mathrm{mg}$ medroxyprogesterone and 9 were on OCs such as Microlut, a progesterone-only pill (0.035 mg norethindrone) or Microgynon, which is a combination of estrogen and progesterone $[(0.03 \mathrm{mg}$ ethinyl estradiol (EE) and $0.15 \mathrm{mg}$ levonorgestrel (LNG)] and 6 were on Intra Uterine contraceptives (Optima Intra uterine copper contraceptives model Tcu380A). Twentyfive were controls who have not used any form of contraceptive for the past 2 years (Tables 1 and 2). The mean duration for the contraceptive use was 9.08 months.

Table 2: Biochemical parameters of participants.

\begin{tabular}{|c|c|c|c|}
\hline Parameter & Control & Case & p-value \\
\hline $\begin{array}{l}\text { Age } \\
\text { (years) }\end{array}$ & $28.92 \pm 9.76$ & $30.60 \pm 7.82$ & 0.505 \\
\hline $\begin{array}{l}\text { SBP } \\
(\mathrm{mmHg})\end{array}$ & $106.40 \pm 10.36$ & $110.24 \pm 11.75$ & 0.2264 \\
\hline $\begin{array}{l}\text { DBP } \\
(\mathrm{mmHg})\end{array}$ & $64.00 \pm 8.66$ & $71.16 \pm 11.31$ & $0.0153 *$ \\
\hline $\begin{array}{l}\mathrm{TG} \\
(\mathrm{mmol} / \mathrm{L})\end{array}$ & $0.78 \pm 0.3$ & $0.86 \pm 0.37$ & 0.4267 \\
\hline $\begin{array}{l}\text { TC } \\
(\mathrm{mmol} / \mathrm{L})\end{array}$ & $5.13 \pm 0.84$ & $4.65 \pm 1.05$ & 0.0787 \\
\hline $\begin{array}{l}\text { HDLC } \\
(\mathrm{mmol} / \mathrm{L})\end{array}$ & $1.58 \pm 0.35$ & $1.28 \pm 0.26$ & $0.001 *$ \\
\hline $\begin{array}{l}\text { LDLC } \\
(\mathrm{mmol} / \mathrm{L})\end{array}$ & $3.21 \pm 0.66$ & $2.98 \pm 0.92$ & 0.3004 \\
\hline $\begin{array}{l}\text { VLDLC } \\
(\mathrm{mmol} / \mathrm{L})\end{array}$ & $0.35 \pm 0.14$ & $0.39 \pm 0.17$ & 0.4034 \\
\hline $\begin{array}{l}\mathrm{CR} \\
\text { (TC/HDL) }\end{array}$ & $4.57 \pm 0.85$ & $5.11 \pm 1.2$ & 0.0728 \\
\hline $\begin{array}{l}\text { BMI } \\
\left(\mathrm{kg} / \mathrm{m}^{2}\right)\end{array}$ & $22.48 \pm 4.2$ & $22.52 \pm 4.14$ & 0.9704 \\
\hline $\begin{array}{l}\text { Duration } \\
\text { (months) }\end{array}$ & - & $9.08 \pm 5.69$ & - \\
\hline $\begin{array}{l}\text { Log } \\
\text { TG/HDLC }\end{array}$ & $-0.32 \pm 0.16$ & $-0.20 \pm 0.17$ & 0.0101 \\
\hline
\end{tabular}

Data presented as mean $\pm \mathrm{SD}, \mathrm{SBP}=$ Systolic blood pressure, $\mathrm{DBP}=$ Diastolic blood pressure, $\mathrm{TG}=$ Triglycerides, $\mathrm{TC}=$ Total cholesterol, HDLC=High density lipoprotein cholesterol, LDLC=Low density lipoprotein cholesterol, VLDLC=Very low density lipoprotein cholesterol, $\mathrm{CR}=$ Coronary risk, $\mathrm{BMI}=\mathrm{Body}$ mass index, $\log$ TG/HDLC $=$ Atherogenic index $\mathrm{P}<0.05$; reference intervals: $\mathrm{TC}=3.60-6.20 \mathrm{mmol} / \mathrm{L} ; \mathrm{TGs}=0.40-2.25$ $\mathrm{mmol} / \mathrm{L} ; \mathrm{HDLC}=1.03-1.55 \mathrm{mmol} / \mathrm{L} ; \mathrm{LDLC}=0-3.90 \mathrm{mmol} / \mathrm{L}$; VLDLC $<0.65 \mathrm{mmol} / \mathrm{L}$; Coronary risk=0.00-4.40; blood pressure $=110 / 70 \mathrm{mmHg}$; BMI $\left(\mathrm{kg} / \mathrm{m}^{2}\right)<18.5$ (underweight), 18.5-24.9 (normal weight), $>25$ (obesity). $*=$ Statistically significant $(\mathrm{p}<0.05)$.

There was no significant difference between the controls and the cases when total cholesterol (TC), LDL cholesterol, triglycerides (TG) and very low-density lipoprotein (VLDL) levels were compared. The SPB did not differ much between the cases and the controls. However, there was significant difference in the DBP between the cases $(71.16 \pm 11.31 \mathrm{mmHg})$ and controls $(64.00 \pm 8.66 \mathrm{mmHg}), \quad \mathrm{p}=0.0153$. The mean HDL concentration for the control group $(1.58 \pm 0.35)$ and cases $(1.28 \pm 0.26)$ was statistically significant $(\mathrm{p}=0.001)$. The atherogenic index $(\log$ TG/HDL) was $-0.32 \pm 0.16$ and $0.20 \pm 0.17$ for the control and case groups respectively and showed statistically significant difference $(\mathrm{p}=0.0101)$ (Table 2). The BMI $(\mathrm{p}=0.9704)$ and the coronary risk (CR) $(\mathrm{p}=0.0728)$ did not also show significant differences between the groups (Table 2).

Table 3: Biochemical parameters of women using implant.

\begin{tabular}{|llll|}
\hline $\begin{array}{l}\text { Parameter } \\
\text { Age } \\
\text { (years) }\end{array}$ & $28.92 \pm 9.76$ & $28.44 \pm 6.36$ & 0.8376 \\
\hline $\begin{array}{l}\text { SBP } \\
\text { (mmHg) }\end{array}$ & $106.80 \pm 13.45$ & $110.24 \pm 11.75$ & 0.3404 \\
\hline $\begin{array}{l}\text { DBP } \\
(\mathrm{mmHg})\end{array}$ & $66.00 \pm 11.55$ & $71.16 \pm 11.31$ & 0.1169 \\
\hline $\begin{array}{l}\text { TG } \\
(\mathrm{mmol} / \mathrm{L})\end{array}$ & $0.78 \pm 0.3$ & $0.72 \pm 0.3$ & 0.4677 \\
\hline $\begin{array}{l}\text { TC } \\
(\mathrm{mmol} / \mathrm{L})\end{array}$ & $5.13 \pm 0.84$ & $4.48 \pm 1.01$ & 0.0164 \\
\hline $\begin{array}{l}\text { HDLC } \\
(\mathrm{mmol} / \mathrm{L})\end{array}$ & $1.58 \pm 0.35$ & $1.22 \pm 0.24$ & 0.0001 \\
\hline $\begin{array}{l}\text { LDLC } \\
(\mathrm{mmol} / \mathrm{L})\end{array}$ & $3.21 \pm 0.66$ & $2.93 \pm 0.91$ & 0.2178 \\
\hline $\begin{array}{l}\text { VLDLC } \\
(\mathrm{mmol} / \mathrm{L})\end{array}$ & $0.35 \pm 0.14$ & $0.33 \pm 0.14$ & 0.5203 \\
\hline $\begin{array}{l}\text { CR } \\
(\mathrm{TC} / \mathrm{HDL})\end{array}$ & $4.57 \pm 0.85$ & $5.25 \pm 1.51$ & 0.0452 \\
\hline $\begin{array}{l}\text { BMI } \\
\left(\mathrm{kg} / \mathrm{m}^{2}\right)\end{array}$ & $22.52 \pm 4.14$ & $23.07 \pm 4.5$ & 0.6563 \\
\hline $\begin{array}{l}\text { Duration } \\
(\mathrm{months})\end{array}$ & - & $11.32 \pm 5.73$ & - \\
\hline $\begin{array}{l}\text { Log } \\
\text { TG/HDLC }\end{array}$ & $-0.32 \pm 0.16$ & $-0.25 \pm 0.22$ & 0.2316 \\
\hline
\end{tabular}

When the data was stratified according to the type of contraceptive use, there were significant differences between implant users and the controls with regards to TC levels $(5.13 \pm 0.84 \mathrm{mmol} / \mathrm{L}$ verus $4.48 \pm 1.01 \mathrm{mmol} / \mathrm{L}$, $\mathrm{p}=0.016)$ and HDL levels $(1.58 \pm 0.35 \mathrm{mmol} / \mathrm{L}$ vs. $1.22 \pm 0.22 \mathrm{mmol} / \mathrm{L}, \mathrm{p} \leq 0.0001)$. When the $\mathrm{CR}(\mathrm{TC} / \mathrm{HDL})$ for the controls and Implants were compared, those on Implant had increased CR $(5.25 \pm 1.51)$ compared to CR of $4.57 \pm 0.85$ for the controls $(\mathrm{p}=0.0452)$. There were, however, no significant differences in age, TG, blood pressure, and BMI between the implants and controls (Table 3).

There was significant difference $(\mathrm{p}=0.0299)$ in the HDL cholesterol levels between the controls $(1.58 \pm 0.35$ $\mathrm{mmol} / \mathrm{L})$ and the ICs $(1.38 \pm 0.98 \mathrm{mmol} / \mathrm{L})$. 
Table 4: Biochemical parameters of women using injectable contraceptives.

\begin{tabular}{|llll|}
\hline Parameter & Control & Injectable & p-value \\
\hline $\begin{array}{l}\text { Age } \\
\text { (years) }\end{array}$ & $28.92 \pm 9.76$ & $32.64 \pm 7.47$ & 0.1367 \\
\hline $\begin{array}{l}\text { SBP } \\
\text { (mmHg) }\end{array}$ & $110.24 \pm 11.75$ & $112.88 \pm 18.14$ & 0.5443 \\
\hline $\begin{array}{l}\text { DBP } \\
(\mathrm{mmHg})\end{array}$ & $65.20 \pm 9.63$ & $74.16 \pm 11.31$ & 0.049 \\
\hline $\begin{array}{l}\text { TG } \\
(\mathrm{mmol} / \mathrm{L})\end{array}$ & $0.78 \pm 0.3$ & $0.86 \pm 0.36$ & 0.4476 \\
\hline $\begin{array}{l}\text { TC } \\
(\mathrm{mmol} / \mathrm{L})\end{array}$ & $5.13 \pm 0.84$ & $4.88 \pm 0.98$ & 0.3334 \\
\hline $\begin{array}{l}\mathrm{HDLC} \\
(\mathrm{mmol} / \mathrm{L})\end{array}$ & $1.58 \pm 0.35$ & $1.38 \pm 0.31$ & 0.0299 \\
\hline $\begin{array}{l}\text { LDL } \\
(\mathrm{mmol} / \mathrm{L})\end{array}$ & $3.21 \pm 0.66$ & $3.11 \pm 0.84$ & 0.6424 \\
\hline $\begin{array}{l}\text { VLDLC } \\
(\mathrm{mmol} / \mathrm{l})\end{array}$ & $0.35 \pm 0.14$ & $0.39 \pm 0.17$ & 0.4301 \\
\hline $\begin{array}{l}\text { CR } \\
(\mathrm{TC} / \mathrm{HDL})\end{array}$ & $4.57 \pm 0.85$ & $5.07 \pm 1.19$ & 0.0956 \\
\hline $\begin{array}{l}\text { BMI } \\
\left(\mathrm{kg} / \mathrm{m}^{2}\right)\end{array}$ & $22.52 \pm 4.14$ & $23.12 \pm 5.44$ & 0.6628 \\
\hline $\begin{array}{l}\text { Duration } \\
(\mathrm{months})\end{array}$ & - & $8.60 \pm 3.99$ & - \\
\hline $\begin{array}{l}\text { Log } \\
\text { TG/HDLC }\end{array}$ & $-0.32 \pm 0.16$ & $-0.23 \pm 0.2$ & 0.062 \\
\hline
\end{tabular}

Table 5: Biochemical parameters of women using oral contraceptives.

\begin{tabular}{|llll|}
\hline Parameter & Control & Oral & p-value \\
\hline $\begin{array}{l}\text { Age } \\
\text { (years) }\end{array}$ & $28.92 \pm 9.76$ & $29.00 \pm 6.69$ & 0.9821 \\
\hline $\begin{array}{l}\text { SBP } \\
\text { (mmHg) }\end{array}$ & $110.24 \pm 11.75$ & $103.33 \pm 10$ & 0.127 \\
\hline $\begin{array}{l}\text { DBP } \\
\text { (mmHg) }\end{array}$ & $64.44 \pm 7.26$ & $71.16 \pm 11.31$ & 0.1078 \\
\hline $\begin{array}{l}\text { TG } \\
\text { (mmol/L) }\end{array}$ & $0.78 \pm 0.3$ & $0.74 \pm 0.21$ & 0.6905 \\
\hline $\begin{array}{l}\text { TC } \\
(\mathrm{mmol} / \mathrm{L})\end{array}$ & $5.13 \pm 0.84$ & $4.58 \pm 1.04$ & 0.1211 \\
\hline $\begin{array}{l}\mathrm{HDLC} \\
(\mathrm{mmol} / \mathrm{L})\end{array}$ & $1.58 \pm 0.35$ & $1.45 \pm 0.28$ & 0.3115 \\
\hline $\begin{array}{l}\mathrm{LDLC} \\
(\mathrm{mmol} / \mathrm{L})\end{array}$ & $3.21 \pm 0.66$ & $2.79 \pm 0.86$ & 0.1327 \\
\hline $\begin{array}{l}\text { VLDLC } \\
(\mathrm{mmol} / \mathrm{L})\end{array}$ & $0.35 \pm 0.14$ & $0.34 \pm 0.09$ & 0.7192 \\
\hline $\begin{array}{l}\mathrm{CR} \\
\text { (TC/HDL) }\end{array}$ & $4.57 \pm 0.85$ & $4.40 \pm 0.91$ & 0.6159 \\
\hline $\begin{array}{l}\text { BMI } \\
\left(\mathrm{kg} / \mathrm{m}^{2}\right)\end{array}$ & $22.52 \pm 4.14$ & $23.20 \pm 4.29$ & 0.6802 \\
\hline $\begin{array}{l}\text { Duration } \\
(\mathrm{months})\end{array}$ & - & $6.33 \pm 4$ & - \\
\hline $\begin{array}{l}\text { Log } \\
\text { TG/HDL }\end{array}$ & $-0.32 \pm 0.16$ & $-0.30 \pm 0.12$ & 0.715 \\
\hline
\end{tabular}

The DBP also showed significant difference $(=0.049)$ between those using IC and the controls. The SBP, the TG, LDL and VLDL did not show statistically significant differences between the ICs and the controls (Table 4).

Table 6: Biochemical parameters of women using IUD contraceptives.

\begin{tabular}{|llll|}
\hline $\begin{array}{l}\text { Parameter } \\
\text { Age } \\
\text { (years) }\end{array}$ & $28.92 \pm 9.76$ & $38.67 \pm 5.2$ & 0.026 \\
\hline $\begin{array}{l}\text { SBP } \\
(\mathrm{mmHg})\end{array}$ & $110.24 \pm 11.75$ & $111.00 \pm 15.17$ & 0.756 \\
\hline $\begin{array}{l}\text { DBP } \\
(\mathrm{mmHg})\end{array}$ & $72.16 \pm 11.31$ & $71.00 \pm 13.78$ & 0.6987 \\
\hline $\begin{array}{l}\text { TG } \\
(\mathrm{mmol} / \mathrm{L})\end{array}$ & $0.78 \pm 0.3$ & $0.68 \pm 0.31$ & 0.4419 \\
\hline $\begin{array}{l}\text { TC } \\
(\mathrm{mmol} / \mathrm{L})\end{array}$ & $5.13 \pm 0.84$ & $5.22 \pm 1.3$ & 0.8341 \\
\hline $\begin{array}{l}\mathrm{HDLC} \\
(\mathrm{mmol} / \mathrm{L})\end{array}$ & $1.58 \pm 0.35$ & $1.49 \pm 0.38$ & 0.559 \\
\hline $\begin{array}{l}\mathrm{LDLC} \\
(\mathrm{mmol} / \mathrm{L})\end{array}$ & $3.21 \pm 0.66$ & $3.43 \pm 1.04$ & 0.5255 \\
\hline $\begin{array}{l}\text { VLDLC } \\
(\mathrm{mmol} / \mathrm{L})\end{array}$ & $0.35 \pm 0.14$ & $0.31 \pm 0.14$ & 0.4698 \\
\hline $\begin{array}{l}\text { CR } \\
(\mathrm{TC} / \mathrm{HDL})\end{array}$ & $4.57 \pm 0.85$ & $4.97 \pm 1.29$ & 0.353 \\
\hline $\begin{array}{l}\text { BMI } \\
\left(\mathrm{kg} / \mathrm{m}^{2}\right)\end{array}$ & $22.52 \pm 4.14$ & $25.13 \pm 3.41$ & 0.1649 \\
\hline $\begin{array}{l}\text { Duration } \\
(\mathrm{months})\end{array}$ & - & $17.17 \pm 11.69$ & - \\
\hline $\begin{array}{l}\text { Log } \\
\text { TG/HDL }\end{array}$ & $-0.32 \pm 0.16$ & $-0.37 \pm 0.15$ & 0.5244 \\
\hline
\end{tabular}

Comparison between the OCs and the controls (Table 5) as well as between the IUDs and the controls (Table 6) did not show any significant difference in the all the parameters under consideration.

\section{DISCUSSION}

The results of this study indicate that those using contraceptives were generally older than the controls though no significant difference existed between them. There was no significant difference between the controls and the cases with regards to the SBP although the cases had generally increased in SBP. However, the DBP showed significant difference between the cases and the controls with the cases having higher DBP. Nonetheless the values were generally within normal values. This was as a result of the short duration of contraceptive use of clients recruited for this study and hence the abnormal changes which could have been distinguished over time were not realized.

Upon stratification of the data, the significant differences observed were largely coming from those using injectable contraceptive which contains depot medroxyprogesterone acetate. This is similar to what was reported in a 
community based study of adult females from the Zongo community attending a Reproductive Healthcare Clinic in Wa, Ghana. ${ }^{2}$ The study in Wa also found DBP to be significantly higher among implant users which is different from what is being reported in this present study. Those who were on OC showed no significant difference when they were compared to the controls. There were slight increases in the BMI and the DBP levels of the participants on $\mathrm{OC}$ but there was no significant difference. The results of this study are again different from another study which reported significantly higher DBP in those using OC as compared to those on other forms of contraceptives. ${ }^{12}$ The increases in BMI and DBP of this present study are predictive of a possible effect on cardiac function if women were placed on $\mathrm{OC}$ over a long period of time.

The differences between what is being reported from this present study and the study by investigators in Wa could be as a result of differences in the duration of the contraceptive use. Whereas their study involved participants who used OC, IMPLANT, and IC for 94, 83 and 43 months respectively, this present study examined participants with relatively shorter duration of contraceptive use for a period of 6,11 and 8 months respectively for OC, IMPLANT and IC users. It is however, important to note that, the concordance of this study with that of previously published work, on the increase of DBP which is regarded as a pre-hypertension marker, following hormonal contraceptive use and more especially the IC, is due to the effect of the medroxyprogesterone acetate on weight gain which is a risk factor for increase in blood pressure. ${ }^{12,13}$ This suggests that prolong use of these HCs could be predisposing conditions for the development of hypertension. The BMI of those on $\mathrm{HC}$ as well as those using IUD were generally higher than those not using any form of contraceptives though the difference was not statistically significant. The increases of the BMI levels in this study were observed to be high in women using OC followed by those on IC and then IMP. This pattern follows a report shown in a study in Ghana by Asare and his colleagues. ${ }^{2}$ The significant differences in BMI shown in the work of Asare et al could be attributed to the long duration of contraceptive use of women on their study as compared to short time range of our subjects on this study.

This study has shown generally higher increases in TG levels among the contraceptive users than the controls though there was no significant difference between them. When the data was stratified according to the type of contraceptives, there were no significant differences in the TG levels for those on implant and non-users. The insignificant changes in the TG level are due the short duration (11.32 \pm 5.73$)$ months of implant use. A similar trend was observed in another study on Egyptian women where a short duration of contraceptive use resulted in no significance difference. ${ }^{14}$ Additionally, for HDL, the implant showed a significant reduction while the TC significantly increased which is in consonance with what was reported in Egyptian women. ${ }^{14}$ The reduction in HDL and increase in TC resulted in statistically significant increased CR. This implies that prolonged use may lead to cardiovascular diseases, indicating that it is relatively safe for women to use contraceptives (IMP) for a short period. Other relevant studies in this field have shown a significant increase in the TG, LDL and VLDL levels of women using contraceptives for a period above 3 years. ${ }^{15}$ It is therefore good for short term users.

The atherogenic index showed significant difference between those on contraceptives and the controls. The atherogenic index is an indicator of atherosclerosis. It suggests that atherogenesis is on-going, and a possible endothelial injury might have occurred. When there is endothelial injury, macrophages move to the site to clear off oxidized LDL. Macrophages ingest extra lipids and become foam cells, releasing cytokines with the consequent increase in cell proliferations and a further decrease in the diameter of the lumen of blood vessels; this hardens to form a plaque within the lumen. If not corrected, there is the possibility of one developing myocardial infarction and possibly ending up in death. ${ }^{16}$ Though the values of the atherogenic index for those on contraceptive is within the normal range, it is possible for these women to suffer stroke or any of the CVDs if they are allowed to stay on contraceptives for a longer period of time, considering the significant differences observed in this study.

Similarly, those on IC had higher TG levels. The TG levels were, however, within the normal values and hence did not show any significance. This is similar to one study on the effect of hormonal contraception on systemic metabolism where TG was observed to be slightly increased among contraceptive users and also similar to what was reported in a community-based study in Ghana. ${ }^{2,17}$ There was no statistically significant difference for the LDL and VLDL when the controls and IC were compared. Again, the study revealed that the duration with regards to IC was shorter $(8.60 \pm 3.99)$ months and this could have accounted for the insignificant differences observed. This is similar to the observations made by Fahmy et al. ${ }^{14}$ The HDL levels, however, have shown reduction for the women on IC as compared to those who are not on it as was seen in those on IMP, but the reduction in the levels were not significant which lead to an insignificant CR. It may be attributed to the shorter duration period of IC users compared to IMP (8 months and 11 months respectively).

The duration of use was shorter for those who were place on OC $(6.33 \pm 4.0)$ months as compared to both IMP and IC and hence the changes in the various lipid parameters were not realized. A similar study by Mina and colleagues investigating the effect of the different durations of contraceptive use on lipids revealed that possible significant increases may occur in TC and HDL 
levels if OC use was extended over a long period of time (12 months and above). ${ }^{18}$

The IUD's did not show statistically significant differences for all the parameters as compared to the control. The average duration for the IUDs was 17.17 months indicating relatively longer duration compared to the other forms of contraceptives. This suggests that for the IUDs the non-significant differences observed was not as a result of any hormonal effect since it is basically a barrier method and the copper metal has not been shown to have any effect on lipid metabolism.

\section{CONCLUSION}

The observations made from this study reveals that shorter duration of HC contraceptive use may lead to minimal effects in lipids metabolism and atherogenesis. It is therefore safe for clinicians to prescribe hormonal contraceptives to clients over short period of time.

IUDs from this study have little or no effect on atherogenic dyslipidemia and hence women should be encouraged to use this method of contraception. Blood Pressure was increased in this study for IC and slight increases with OC and IMP indicating a gradual effect of hormonal contraceptive use on cardiac function. Since DBP is an early marker for increased blood pressure (Prehypertension marker), it is necessary to continually monitor the BP of women on HC.

\section{ACKNOWLEDGMENTS}

The authors are grateful to the staff of the Reproductive Health unit, the staff of the laboratory department and the management of the Volta Regional Hospital for granting them permission to carry out the project in the facility.

Funding: No funding sources

Conflict of interest: None declared

Ethical approval: The study was approved by the University of Health and Allied Sciences' Research Ethical Committee. Protocol number: UHASREC/A.5[40]17

\section{REFERENCES}

1. Frempong BA, Ricks M, Sen S, Sumner AE. Effect of low-dose oral contraceptives on metabolic risk factors in African-American women. J Clinic Endocrinol Metabol. 2008;93(6):2097-103.

2. Asare GA, Santa S, Ngala RA, Asiedu B, Afriyie D, Amoah AG. Effect of hormonal contraceptives on lipid profile and the risk indices for cardiovascular disease in a Ghanaian community. Int $\mathrm{J}$ Women's Health. 2014;6:597.

3. Health, W. H. O. D. o. R.; Research; Johns Hopkins Bloomberg School of Public Health/Center for Communication Programs, K. F. H. P., Family
Planning: A Global Handbook for Providers (2011 Update). 2011.

4. Kiriwat O, Petyim S. The effects of transdermal contraception on lipid profiles, carbohydrate metabolism and coagulogram in Thai women. Gynecol Endocrinol. 2010;26(5):361-5.

5. Torkzahrani S, Heidari A, Mostafavi-pour Z, Ahmadi M, Zal F. Amelioration of lipid abnormalities by vitamin therapy in women using oral contraceptives. Clinic Exp Reprod Med. 2014;41(1):15-20.

6. Crook D, Godsland IF, Wynn V. Oral contraceptives and coronary heart disease: modulation of glucose tolerance and plasma lipid risk factors by progestins. Am J Obstet Gynecol. 1988;158(6):1612-20.

7. Watanabe RM, Azen CG, Roy SU, Perlman JA, Bergman RN. Defects in carbohydrate metabolism in oral contraceptive users without apparent metabolic risk factors. J Clinic Endocrinol Metabol. 1994;79(5):1277-83.

8. Enk L, Landgren BM, Lindberg UB, Silfverstolpe G, Crona N. A prospective, one-year study on the effects of two long acting injectable contraceptives (depot-medroxyprogesterone acetate and norethisterone oenanthate) on serum and lipoprotein lipids. Hormone Metabol Res. 1992;24(2):85-9.

9. LeBlanc ES, Laws A. Benefits and risks of thirdgeneration oral contraceptives. J Gen Internal Med. 1999;14(10):625-32.

10. Lubianca JN, Faccin CS. Oral contraceptives: a risk factor for uncontrolled blood pressure among hypertensive women. Contracept. 2003;67(1):19-24.

11. Atthobari J, Gansevoort RT, Visser ST, De Jong PE, De Jong-van den Berg LT, PREVEND Study Group. The impact of hormonal contraceptives on blood pressure, urinary albumin excretion and glomerular filtration rate. Brit $\mathrm{J}$ Clinic Pharmacol. 2007;63(2):224-31.

12. Lubianca JN, Faccin CS. Oral contraceptives: a risk factor for uncontrolled blood pressure among hypertensive women. Contracept. 2003;67(1):19-24.

13. Gichuhi JW, Aruasa WK, Oyieke JB, Gichuhi JW. The effect of Depot Medroxyprogesterone acetate contraceptive on body weight and blood pressure in indigenous Kenyan women. Europ Int J Sci Technol. 2014.

14. Fahmy K, Khairy M, Allam G, Gobran F, Alloush M. Effect of depo-medroxyprogesterone acetate on coagulation factors and serum lipids in Egyptian women. Contracept. 1991;44(4):431-44.

15. Berenson AB, Rahman M, Wilkinson G. Effect of injectable and oral contraceptives on serum lipids. Obstet Gynecol. 2009;114(4):786-94.

16. Marshall WJ, Bangert SK. Lipids, lipoproteins and cardiovascular disease. In: Marshall WJ, Bangert SK, eds. Clinical Chemistry. China: Mosby/Elsevier Limited; 2008: 274-275.

17. Wang Q, Würtz $\mathrm{P}$, Auro K, Morin-Papunen L, Kangas AJ, Soininen P, et al. Effects of hormonal contraception on systemic metabolism: cross- 
sectional and longitudinal evidence. Int $\mathbf{J}$ Epidemiol. 2016;45(5):1445-57.

18. Amiri M, Tehrani FR, Nahidi F, Kabir A, Azizi F, Carmina E. Effects of oral contraceptives on metabolic profile in women with polycystic ovary syndrome: A meta-analysis comparing products containing cyproterone acetate with third generation progestins. Metabol. 2017;73:22-35.
Cite this article as: Bawah AT, Boateng MA,

Kuffour FAO, Seini MM, Amoah P, Alidu H. Lipid profile and cardiovascular risk indices of women on various types of contraceptives in the Ho Municipality of Ghana. Int J Reprod Contracept Obstet Gynecol 2018;7:4342-8. 